\title{
Review of Adoption of Disruptive Innovative Practices in Medical Tourism in India
}

\author{
Nityanand Sharma ${ }^{*}$, A. K. Jain', P. K. Gupta ${ }^{2,3}$ and Samidha D. Sharma ${ }^{4}$ \\ 'IMS-DAVV, Indore - 452001, Madhya Pradesh, India; nityanand.sam@gmail.com, ajju34jain@yahoo.co.uk \\ 2IMS-DAVV Indore - 452001, Madhya Pradesh, India \\ 3Prestige Law College, Indore - 452 010, Madhya Pradesh, India; pkgupta_in@yahoo.com \\ 4Saudi Electronic University, Abha, Saudi Arabia; ssharma@seu.edu.sa
}

\begin{abstract}
The Indian Medical Tourism Industry is significantly adding nearly 3\% to the total size of healthcare sector of India. Surgical techniques and healthcare technologies have undergone revolutionary changes in past four decades giving way to early adoption of disruptive innovative practices by the quality conscious and low cost medical tourism industry in India. This secondary data based research paper aims at examining the adoption and use of Disruptive Innovative Practices in Medical Tourism Industry in India. It was concluded that Medical Tourism Industry in India is not only suitable but most probable to adopt and use the Disruptive Innovative Practices. The implication of the paper would be the encouragement of further research on disruptive innovative Practices in Medical care in India.
\end{abstract}

Keywords: Disruptive Innovative Practices, Medical Tourism industry

\section{Introduction}

Disruptive Innovation is a relative phenomenon by definition $^{1,2}$. For a Practice innovation to be disruptive, identifiable actors (market, innovation and organization) that has been clearly disrupted should exist. Clayton defined that the disruptive innovation disrupts the existing market and value network, establish new market and value network and replacing well-known markets of leading firm's product and alliances ${ }^{3}$. The essential feature of Disruptive Innovation is the significant adoption of the innovation. Disruptive Innovative Practices are the practices used by Hospitals and healthcare system involving innovations with specific use in medical care like 'Retail Clinic', medical tourism, m-Health, LASIK surgery, health insurance, G-Scans and Robotic surgery etc. Some of the other Disruptive Innovation Practices in hospitals include Cyber knife robotic radio surgical system, 320-Slice CT Scan, Electronic Health Record (EHR), HIFU-High Intensity Focused Ultrasound etc. The Medical Tourism is in itself Disruptive Innovation where the International Tourists are visiting to developing countries to get cheaper and high quality healthcare services due to certain reasons. Every year, approximately, 0.35 million patients travel from abroad to India mostly for surgeries and indigenous and modern therapies ${ }^{4,5}$ in the hope of low priced yet high-skilled treatment. The key factors that led to an increasing popularity of Medical Tourism is the adoption of innovations in medical care and management which includes Disruptive Innovative Practices and skills available in the developing destination countries, lowering logistic $\cos ^{6,7}$ long waiting times and significantly higher costs in a patient's home country ${ }^{8,9}$ and internet marketing ${ }^{7}$. Country like India, Thailand, Malaysia, Singapore, Philippines, Cuba, Costa Rica, Colombia, Hungary, Jordan, South Africa, South Korea, New Zealand, and Ukraine ${ }^{10}$ have emerged as popular Medical Tourism destinations globally.

The Medical Tourism is an international economic phenomenon influenced largely by the process of Globalization. In India, the business of Medical Tourism started growing after 1991 and now it has assured a significant size and contributing to the G.D.P. The Medical Tourism shows adoption of Disruptive Innovative

\section{${ }^{*}$ Author for correspondence}

[Disclaimer - "The journal, editorial board and publisher cant verify the content of this paper independently, hence the authors are solely responsible for the opinions expressed in this paper"] 
Practices by hospitals. Early adopters include the hospital which can afford, use and get return out of these practices. These types of hospitals are Tourism Hospitals of India. Information Technology enables the Medical Tourism Industry in a country or globally advises patients for best treatment of disease anywhere in the world. According to report Indian mobile industry is probable to attain $\$ 0.6$ billion in 2017. Indian Telemedicine market in 2012, was appreciated at $\$ 7.5$ million, and is probable to grow at a CAGR of $20 \%$ to $\$ 18.7$ million by 2017 .

The Tourism Hospitals acquire the latest innovative practices which includes Disruptive Innovative Technologies also. No research has been found on disruptive innovation practices in medical tourism till date. This study is an attempt to review the adoption in Disruptive Innovation practices by the Tourism Hospitals in India.

\section{Literature Review}

The researchers explored that the robotic surgery is invented to increase the quality of care, it denotes a very important disruptive innovation in the field of healthcare ${ }^{11}$. The researchers summarized that by robotic surgery precision is very much possible. Keeping that in mind, innovated highly sophisticated surgical robots those have been invented to aid in fast growing variety of operative procedures as well as anatomical targets. Disruptive innovation has a potential to provide better operational precision, which may improve scientific medical results and helping to enhance corporate revenues in the technology sector of healthcare. Barbash and Glied ${ }^{12}$ pointed out that the open surgeries have been disrupted by Da Vinci System with notable effect to cost and volumes of these procedures. Gibbs Cancer Center \& Research, a radiation oncologist, Dr. Julian Jorsey describe that the previous radiation treatment technology was similar to make a house with mallet, pins and handsaw. Tumors can be treated from the brain to lung to prostate by CyberKnife disruptive innovative technology. CyberKnife system is excellent radiation oncology treatment to adjusting, tracking and treating of moving targets with utmost correctness ${ }^{13}$. Bradley identified magnetic guided resonance focused ultrasound as a substitute for surgery in treatment of many types of tumors ${ }^{14}$. Coye et al described management of remote patient was identified as an innovation disrupting the current management of chronic diseases ${ }^{15}$. Developments in enabling technology for physiologic monitoring and telecommunications have made it possible to provide information about a patient's current status to care providers who are at a different location than the patient and at a time different from when the measurement was taken, disrupting real time, inperson clinician-patient interactions in hospitals, home care etc. It further disrupts the common business model which treats the critical illness in hospitals and primary care to shift certain tasks to the patient and non-clinical suppliers. The number of authors ${ }^{16-19}$ identified Genomics, personalized medicine and pharmacogenomics as early disruptive innovation. Telemedicine as a disruptive Innovative technology because all the consultation occurs using audio-visual technology disrupt the conventional in person consultation. Changing the business model or process for delivering a service and opening access to a new consumer group is considered a disruptive innovation. According to Deloitte the treatment cost can go down by enabling disruptive innovative technologies and innovative busing models.

Greenhalgh et al., criticized the building of telecare as a widespread technological solution to the problems to deliver the care, which has provided a new structure of defining quality in telecare and telehealth ${ }^{20}$. They summarized a set of characteristics which user-centered, co-formation, amalgamation and evaluation.

Szold et al point out that the trials of robotic surgery must be done continuouslybecause it has great potential for complex surgeries i.e. bariatric and upper gastrointestinal revisional surgery, oesophageal cancer surgery, complex hepatobiliary surgery, gastric surgery, and rectal surger $y^{21}$ etc. According to Reshma et al, Lifesaving disruptions for example: ToucHb, Next-Generation Genomics, Pont-ofCare testing etc, they talked about the diverse thinking and disruptive innovations that have happened in the field of medicine ${ }^{22}$.

Sultana et al. assessed the proportional importance of factors i.e., competitiveness, destination, service quality, and service cost and tourists attitude from the perspectives of customer in India ${ }^{23}$. Ormond and Sulianti examined medical tourism, proposed that the foreign patient's market size of small and dependent on community's ties between source and destination of foreign countries, instead of a big detached market ${ }^{24}$. Pankaj Mochi found out that because of skilled Indian doctors, medical tourists looking for India as a significant 
destination for healthcare, according to him more than 35,000 Indian doctors serving in USA alone, and caring attitude of Indian nurses regarding treatment, very much appreciated $^{25}$. Mishra R, et al., discovered that there are number of different views from different authors about whether medical tourism is promising industry of has already been established ${ }^{26}$. Medical tourism industry advocated by so many reliable corporations which comprise the Joint Commission International, Medical Tourism Association and the Deloitte Center for Health Solutions. Indian private sector is controlling the Indian medical tourism industry majorly. Forgione and Smith identified the prominent reasons, which encourage the selection of destination for healthcare treatment of foreign patients; those reasons are-less treatment cost, accreditation, and quality of treatment and physician training.

The disruptive innovations included:

\subsection{Patient Self Care}

- Health care Tourism ${ }^{27}$.

- Social Media ${ }^{28}$.

\subsection{Primary Care/Community Care}

- Retail clinics ${ }^{29}$.

- $\quad$ E-Clinic for Drugs ${ }^{30}$.

\subsection{Diagnostic Imaging}

- $\quad$ MR guided focused ultrasound ${ }^{14}$.

- Computing in radiology $y^{31}$.

- Mobile computing platform in radiology

- Imaging ${ }^{33}$.

- Molecular Imaging ${ }^{34}$.

- Nanotechnology $y^{35,36}$.

- 3D Printing $g^{35}$.

2.4 Hospital Based Surgery

- LASIK $^{5}$.

- Advanced robotics ${ }^{37}$.

- Da Vinci Systems ${ }^{12}$.

- CyberKnife System ${ }^{13}$.

- Robotic Surgery ${ }^{45}$.

\subsection{Personalized Medicine/Genomics}

- Personalized medicine-genomics ${ }^{18}$.

- Genomics $^{17}$.

\subsection{Telehealth/Telemedicine}

- Remote Patient Monitoring ${ }^{15}$.

- Telemedicine ${ }^{38}$.

\subsection{ICT - Related Technologies}

- Web based physician order entry ${ }^{39}$.

- Informatics/communications technology $y^{40}$.

- Wireless Technologies ${ }^{41}$.

- MHealth ${ }^{42}$.

- Cloud Computing ${ }^{37}$.

- Internet of things ${ }^{43}$.

- Personal Health Records ${ }^{44}$.

According to Christensen et al described that the medical tourism, surgical robots, retail clinic, single organ hospitals, personalized medicine, and telemedicine are an only few disruptive innovative healthcare models those disrupting the well-established previous models of healthcare along with very lower cost of treatment ${ }^{45}$.

Burns et al defined that the retail clinics as an innovation disruptive of primary care physician practice. Such a clinic may be located at a mall, a drug store or retail store and is generally staffed by nurse practitioners ${ }^{29}$.

Often computer guided imaging or surgical devices were associated with these innovations. LASIK (laserassisted in situ keratomileusis) is one of the best-known examples of computer guided imaging. It clearly disrupted hospitals by moving many eye operations to the valueAdded Process model of the outpatient eye surgery center from the Solution Shop model of the hospital surgery department. Much less surgical skill is needed for LASIK than for the procedure it replaced. As Christensen puts it surgical skills are in effect "embedded in the machine". One implication is that profits flow more to the machine makers than to the physicians. According to Christensen, LASIK is well known example of disruptive innovations in the healthcare because the skills have been transferred from the surgeon to a computer guided imaging machine, while surgeon may utilize their time in some other productive work instead of performing the surgery. It is the time saving, cost effective and painless surgery.

Christensen the LASIK is a good example; it follows a very clear disruptive-innovation paradigm in that the "skill" has moved from an eye surgeon to a machine ${ }^{5}$.

Christensen described that, 3D printing is a classic example of disruptive innovation because 3D printer compares to traditional one is smaller, cheaper and more 
suitable to use. Existing, 3D printing technology is "good enough" to reach the markets, which was earlier not possible ${ }^{35}$.

Christensen et al also note that advances in imaging technology can also disrupt existing centralized imaging practices. Advances in hand-held or portable imaging can disrupt centralized diagnostic imaging units in hospitals that require sophisticated expertise and where patients must be taken to the centralized location. New imaging diagnostics can allow the point of care to shift to clinics, offices, and ultimately homes. Molecular imaging is seen to be disruptive to current models of radiologic practice regarding who performs imaging. Molecular imaging is not a lower cost, lower quality disruptive innovation. Rather, it is an example of a top-down innovation that is more expensive but delivers superior performance, gradually taking root through economies of scale. Downing identified that the aim of personalized treatment is to optimize preventing healthcare policies, while taking advantages of molecular understanding of illness merged with other individual dynamics, to predict the initial stage of illness ${ }^{46}$.

Coye defined that the remote patient management was identified as an innovation disrupting the current management of chronic diseases ${ }^{15}$. Developments in enabling technology for physiologic monitoring and telecommunications have made it possible to provide information about a patient's current status to care providers who are at a different location than the patient and at a time different from when the measurement was taken, disrupting real time, in-person clinician-patient interactions in hospitals, home care. Internet of things is one of the disruptive innovation which entirely disrupt the way by which healthcare is provided, it connects automatically things with other things without human interventions to alert and to inform about the illness in advance, it yields better results, making healthcare more convenience, affordable, accessible and effective. Venkatramanan and Rathina described in Tele health/ Remote Medicine and Mobile Health (mHealth): the innovation of Internet, personal computing, smart phones, mobile phones, and tablet computers has expanded the possibilities of health promotion and prevention, remote monitoring, diagnostics, and sometimes also treatment ${ }^{42,43}$. Nanotechnology is a disruptive innovative technology, it has a potential to early and strong entry into existing and new markets. It may involve a high chance of failure ${ }^{35,36}$.
The authors opined that telemedicine is a disruptive business model or process and Markides said that telemedicine is neither a disruptive technological nor a product innovation, as in telemedicine traditional faceto-face patient-practitioner model is disrupted be distant patient-practitioner contact to facilitate the service devilry ${ }^{35,47,48}$. Personal Health Records (PHR) is one of the disruptive innovation information technology, used by patients to manage and maintain their health related information in secure and confidential environment, it greatly minimize the office visits.

Omid Moghadam, director of PHR program at Intel, described, a PHR as a record "owned and controlled by the patient that incorporates data the patient enters, but also includes authenticated information from all the places the patient is involved with-insurance company, hospital, doctors' offices, labs, and so forth" ${ }^{\prime 9}$. In the light of literature review, this study may be regarded as the first to examine the phenomenon of the Disruptive Innovative Practices in Medical Tourism in India.

\section{Research Methodology}

This research is a descriptive review study based on Secondary data from various sources like Books, Newspapers, Research Journals, United Nations World Tourism Organization Report, E-Journals, Report of Ministry of Tourism, Report of World Travel, Tourism Council Research Articles, and the website www.healthtourism-india.com etc. The charts have been constructed by the authors to improve clarity of the subject with the help of MS-Office using appropriate statistical tools. The objectives are-

- To review the latest scenario of Medical Tourism in India.

- To study the adoption of Disruptive Innovative Practices in Medical Tourism in India.

\section{Observations and Interpretations}

\subsection{Major Hospitals in India Offering Medical Tourism Services}

The map showing major Hospitals catering Medical Tourism in India 


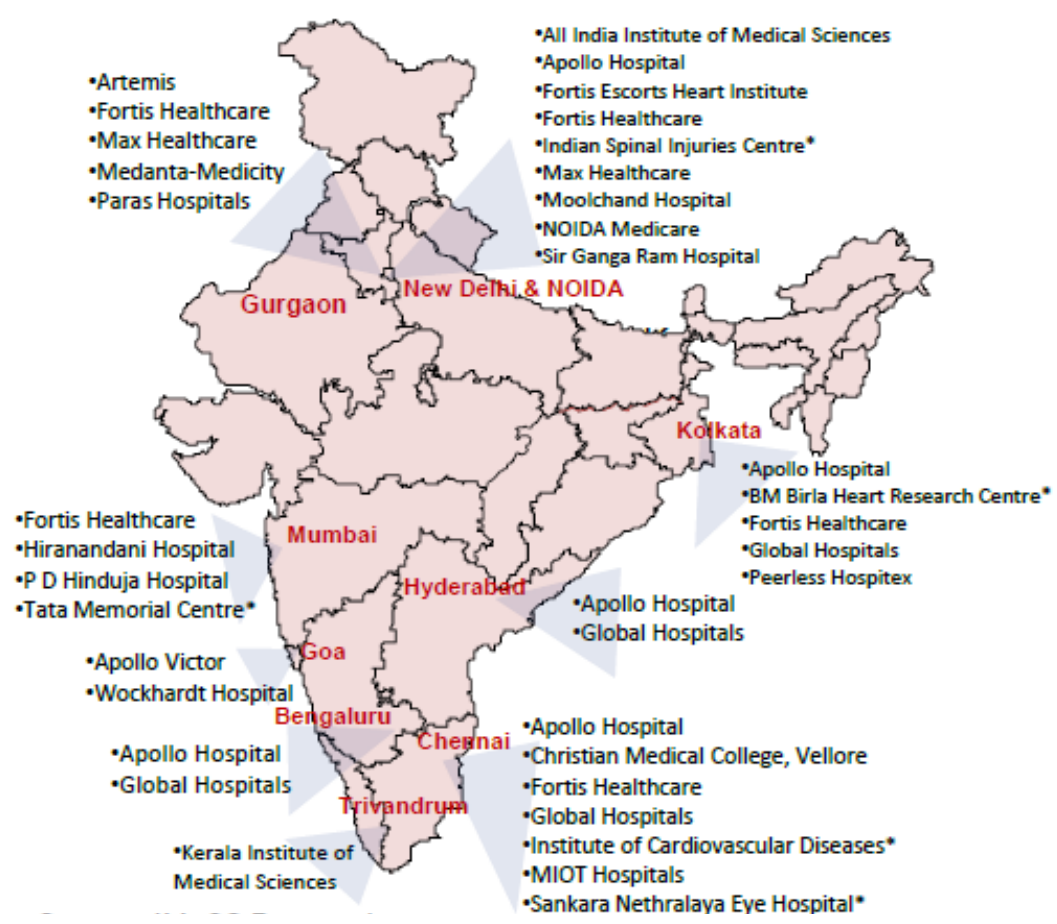

Figure 1. Hospitals in India offering International Medical Tourists Services (Source: IMaCS Research).

Observations and interpretations: The figure depicts that the 38 hospitals are providing Medical Tourism in India and out of thirty-eight, only five are main hospitals of India having major share of Medical Tourists are viz. Apollo Hospital, Fortis Hospitals, Medanta Hospitals, Max Hospital and AIIMS.

\subsection{Market size of healthcare sector in India}

Observations and interpretations: The total size of healthcare sector is projected to reach US\$ US\$ 280 billion in 2020. India healthcare industry is growing fast and estimated to grow further for another 20 years. Therefore, we could forecast that adoption of Disruptive innovations in Healthcare sector would be more \& faster every passing year.

\section{Healthcare Sector Growth Trends (US \$ in Billion)}

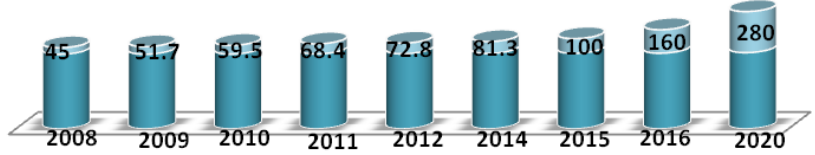

Source: Forst \& Sullivan, LSI Financial Services, Deloitte, TechSci Research

Chart 1. Showing healthcare markets in India.

\subsection{Healthcare Infrastructure in India}

Observations and interpretations: Disease burden is $20 \%$ facing by Indian healthcare sector globally, whereas bad is $6 \%$, which is greatly shortage of beds as per Indian population and only $8 \%$ of doctors and nursing staff available, as for as lab technicians are concerned it is just negligible. Hence there is huge opportunity for disruptive innovations/ technologies to fill the gap like e-health and $\mathrm{m}$-health and other ICT-enabled healthcare services.

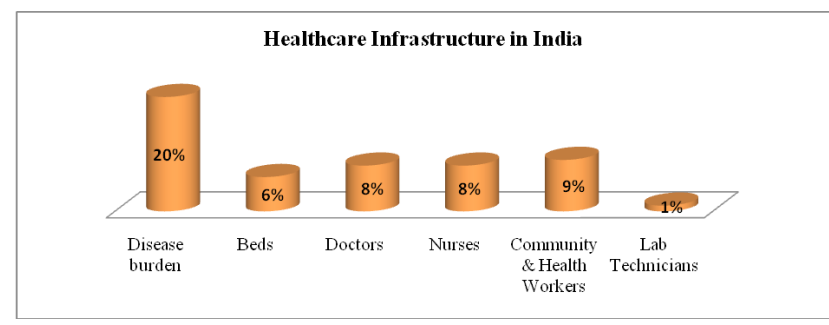

Source: FICCI and E\&Y.

Chart 2. Showing healthcare infrastructure of India.

\subsection{Per Capita Healthcare Expenditure (PCHE)}

Observations and interpretations: Per capita expenditure of Indian healthcare industry $\$ 196$ is the poorest globally, relation with $\$ 8,845$ in USA, \$3,235 in United Kingdom 
and \$578 in China. Hence Indian Government and private companies are introducing various kinds of health insurance schemes which are a type of disruptive innovation in healthcare financing.

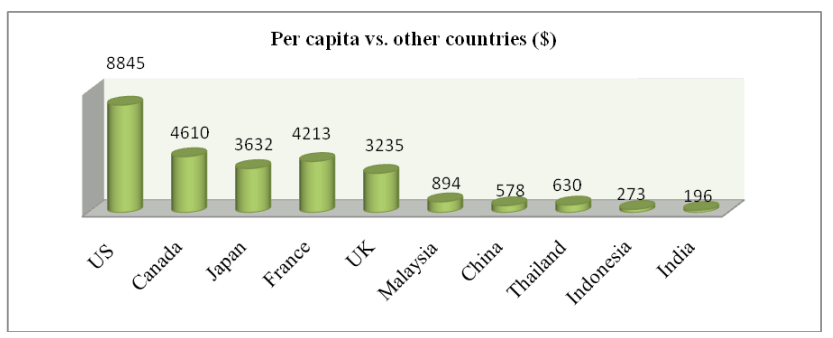

Source: WHO-World Health Statistics 2015

Chart 3. Per capita healthcare expenditure.

\subsection{No. of Hospital Beds for every 10000$$
\text { Populations (Globally) }
$$

Observations and interpretations: Emerging economies of Indian healthcare Infrastructure is a far behind from developed countries the gap is considerable, only 9 beds per 10,000 population much lower than the world whereas 30 beds per 10,000 populations. Henceforth the scope is very large for investment and future growth with increased adoption of disruptive innovations like ambulatory care, day care surgery and home care services to reduce price of services offered with lesser need for hospital beds.

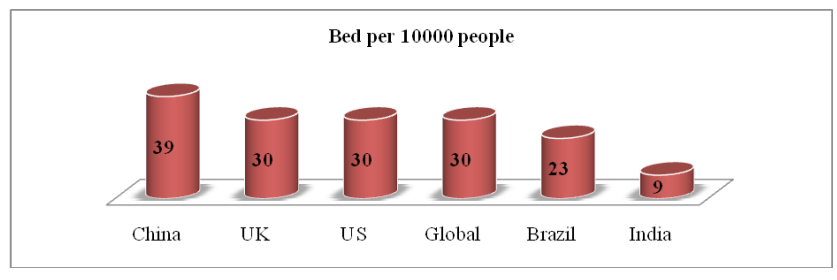

Source: WHO-World Health Statistics 2013

Chart 4. Showing no. of hospital beds per 10,000 populations.

\subsection{Relative Size of Medical Traveler Segments}

Observations and interpretations: There are two prominent reason people travel to other countries one, travelling for freshening up and two, travelling for medical treatment, which is either not available to their home countries or it's very costly. The above graph shows that cost of medical care, lesser waiting time, and betterquality care and advance technology made India preferred destination for tourism healthcare. Modi Government Make in India will further reduce the cost of equipments which are now being imported from developed countries i.e., USA and UK, in medical device industry.

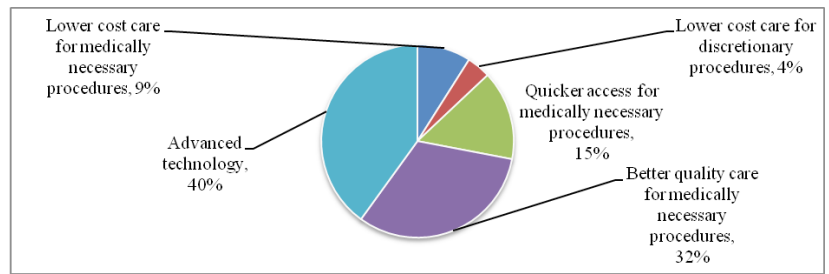

Source: KPMG in India analysis, 2014 (stakeholder feedback)

Chart 5. Relative size of medical traveler traveling to India.

\subsection{Top 10 Ports in Tourism Arrival on e-Tourist Visa during June 2016}

Observations and interpretations: As per the data shown in the chart, the highest Medical Tourists coming to New Delhi as per e-tourist visa issued, followed by Mumbai, Bangalore, Chennai, Hyderabad, Kochi, Kolkata, Ahmadabad, Tiruchirapalli and Trivandrum which comes at the least preferred position to attract the Medical Tourists, it could be analyzed that in New Delhi gets the highest number of Medical Tourists in India due to best hospitals available in the state. It indicates the quantity of adoption of Disruptive Innovative Practices in Medical Tourism of India.

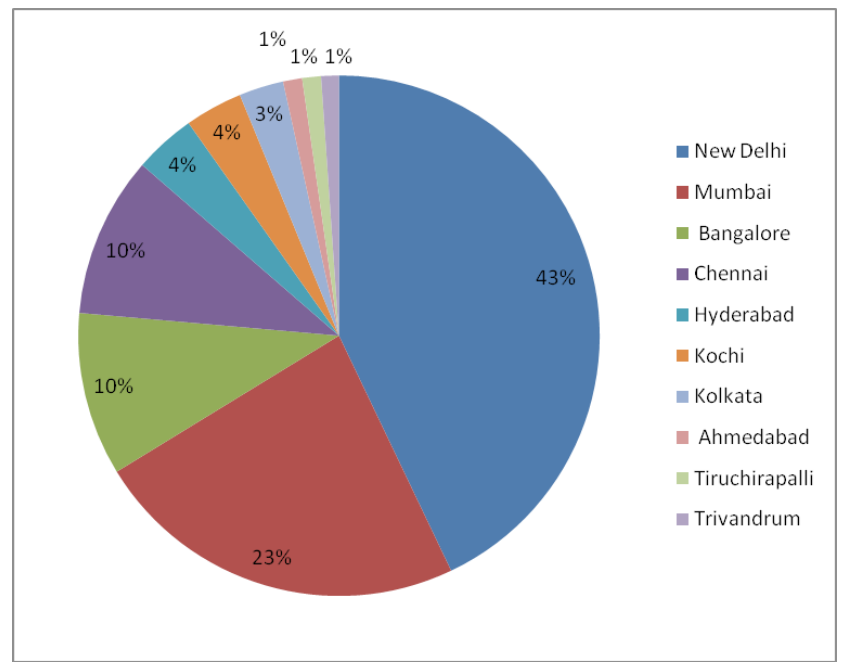

Source: Source: Ministry of Tourism: Press Information Bureau- 22nd May $2016^{50}$.

Chart 6. Medical tourists visiting India-city-wise. 


\subsection{Country-Wise Distribution of} International Society for Quality Care (ISQua) Accreditations Globally (2016)

To encourage Medical Tourists, providers (Hospitals and healthcare institutions) acquire international accreditations. The activity suggests the standardization inside the Medical Tourism Industry (KPMG, 2011). NABH Standard releases in 2007 and accredited through ISQua, it will be terminated in July 2020. The countrywise distribution of is shown below:

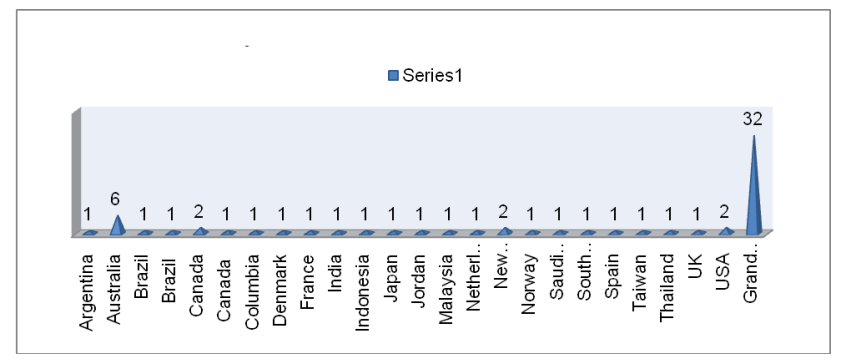

Chart 7. Country-wise distribution of ISQua accreditations (2016).

Observations and interpretations: from the chart, it is depicted that out of 25 countries and 32 Accreditations have been made by now. The analysis shows that the more accreditations are evidence for more standardization and innovative procedures are being followed to encourage Medical Tourists.

\subsection{Country-Wise Distribution of JCI Accredited Hospitals in the World (2016)}

Observations and interpretations: The above chart shows that more than 67 countries have hospitals and healthcare institutions with JCI Accreditations. Two countries i.e., United Arab Emirates (UAE-145 \& Saudi Arabia -105) have more than 100 JCI Accreditations in Healthcare Organizations, three countries i.e., China (61), Thailand (53) and Brazil (51) in the world have more than 50 JCI Accreditations. Five countries i.e., Turkey (47), Ireland (29), India (28), South Korea (27) and Italy (25), have more than 25 Accreditations. These 10 countries in the world have higher number of healthcare organizations are exhaustively involved in the business of Medical Tourism.

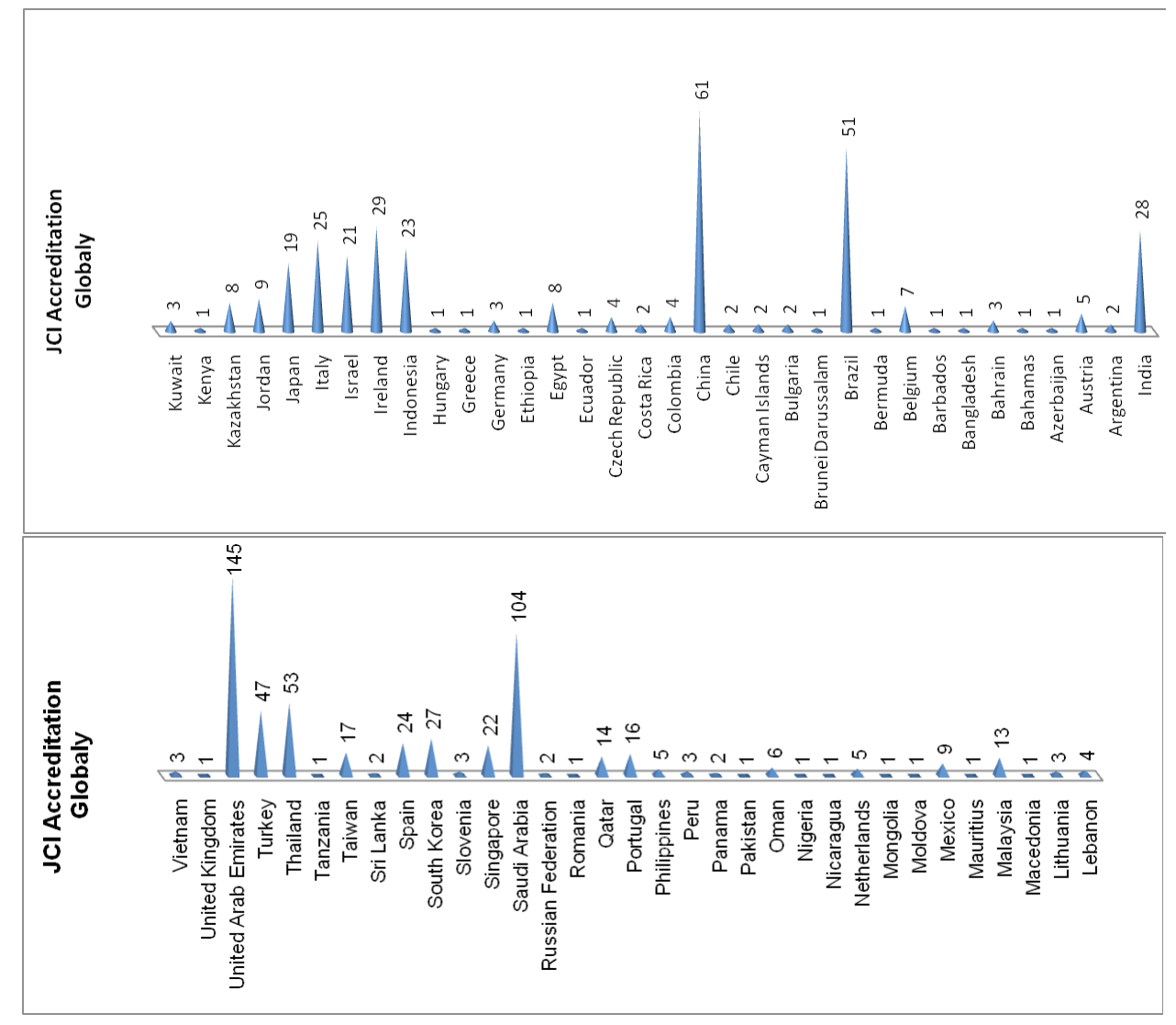

Chart 8. Country-wise distribution of JCI hospitals (2016). 


\subsection{State-Wise Distribution of JCI} Accredited Hospitals in India (2016)

Observations and interpretations: It has been observed that India got 28 Accreditations, whereas out of 12 Indian States, Maharashtra gets higher Accreditations comparing with other States of India. Hence it could be said that Maharashtra has a better position in regards of Medical Tourism standardization.

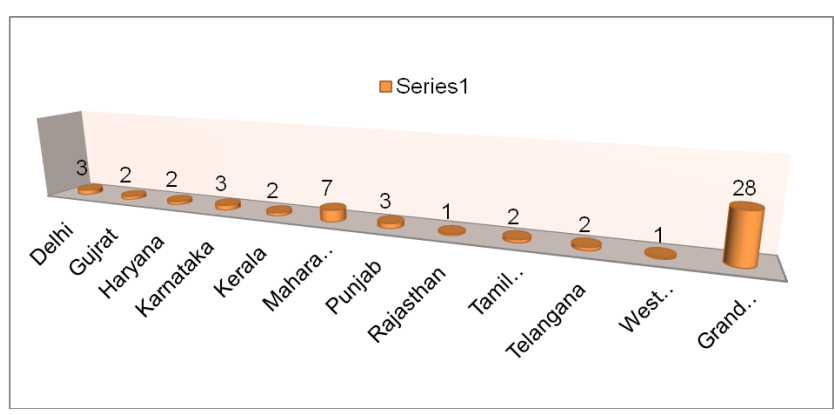

Chart 9. State-wise distribution of JCI hospitals in India (2016).

\subsection{City-Wise Distribution of JCI Accredited Hospitals in India (2016)}

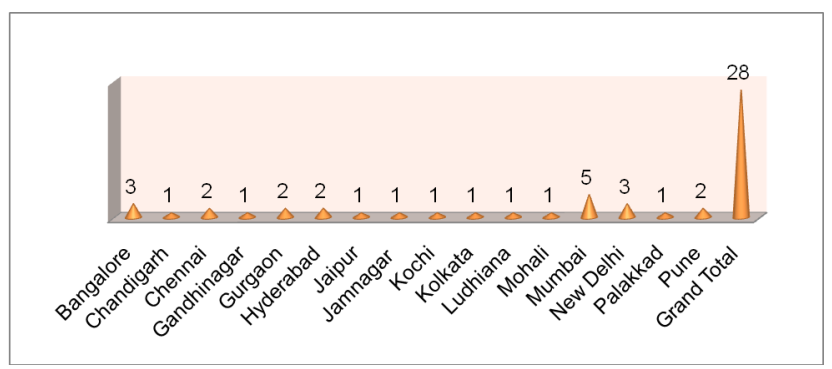

Chart 10. City-wise distribution of JCI accredited hospitals in India (2016).

Table 1. Showing disruptive healthcare technologies

\begin{tabular}{|l|l|l|}
\hline Disruptive Medicare Technology & Critical Illness/Usability & Disrupted Medical Technology \\
\hline $\begin{array}{l}\text { Robotics Surgery (da Vinci Surgi- } \\
\text { cal System) }\end{array}$ & $\begin{array}{l}\text { Urology, Gynaecology, Cardiac, Gastrointestinal Surgery, } \\
\text { Bariatrics, and Paediatrics. Congenital Defects, Ureteropelvic } \\
\text { Junction Obstruction, Uterine and Cervical Cancer, Coronary } \\
\text { Artery Disease, colorectal surgeries, Liver Disease }\end{array}$ & $\begin{array}{l}\text { Traditional surgery with a large } \\
\text { open incision or laparoscopy }\end{array}$ \\
\hline $\begin{array}{l}\text { CyberKnife Robotic Radio Sur- } \\
\text { gery }\end{array}$ & $\begin{array}{l}\text { World's first robotic radio surgery system is designed to treat } \\
\text { tumors anywhere in the whole body. }\end{array}$ & Open Surgery \\
\hline $\begin{array}{l}\text { Renaissanc Robotic Surgical } \\
\text { System }\end{array}$ & Technology specifically designed for spine surgery. & Open-back surgery \\
\hline 320 Slice CT Scanner Technology & $\begin{array}{l}\text { Innovative Imaging system which scans the whole body from } \\
\text { head to toe. Scan heart valve area prior to or after valve sur- } \\
\text { gery, it also diagnoses heart tumors. }\end{array}$ & X Rays \\
\hline TrueBeam STX System & $\begin{array}{l}\text { Radiation cancers therapy: Neuro-Oncology, Thoracic Oncol- } \\
\text { ogy, Gastro-Intestinal Oncology, Genitourinary Oncology }\end{array}$ & Surgery \\
\hline
\end{tabular}
hospitals in India (2016).

Observations and interpretations: The above chart illustrate that out of 22 states, Andhra Pradesh, Delhi and Maharashtra have larger number of $\mathrm{NABH}$ Accredited Hospital, hence these States appeal to Medical Tourists in India considerably.

\subsection{Disruptive Innovative Practices in Tourism Hospitals in Indian}

Observations and interpretations: The above table shows number of Disruptive Innovative Practices adopted by Tourism Hospitals in India to encourage the Medical Tourists from all over the world.

Observations and interpretations: The above chart shows that out of 16 cities, Mumbai, New Delhi and Bangalore have larger number of JCI Accredited Hospital, therefore these cities attract Medical Tourists in India significantly.

\subsection{State-Wise Distribution of NABH Accredited Hospitals in India (2016)}

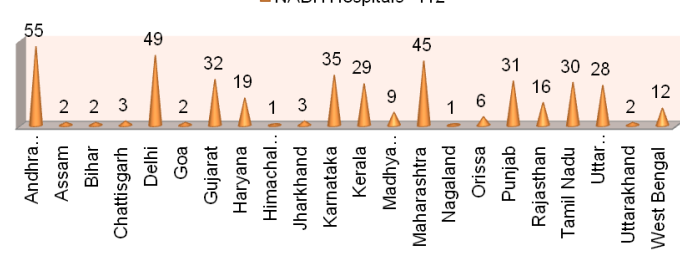




\begin{tabular}{|l|l|l|}
\hline G (Gravity) Scan & $\begin{array}{l}\text { First-of-its-kind cutting edge technology, open standing MRI } \\
\text { scanner }\end{array}$ & Old MRI Machine \\
\hline $\begin{array}{l}\text { Telemedicine / Tele-health / } \\
\text { mHealth / Electronic Medical } \\
\text { Records (EMRs) }\end{array}$ & Remote diagnosis and treatment of patients & Traditional Model of diagnosis \\
\hline Tele-cardiology & $\begin{array}{l}\text { Broadcast of radiological patient images such as x-rays, CTs, } \\
\text { and MRIs, from one remote location to another. }\end{array}$ & Traditional Model of diagnosis \\
\hline $\begin{array}{l}\text { High Intensity Focused Ultra- } \\
\text { sound (HIFU) }\end{array}$ & Treatment of Cancer & Surgery to remove the tumor \\
\hline Robotic Prostate Cancer Surgery & Prostate Cancer & Laparoscopic surgical method \\
\hline $\begin{array}{l}\text { Tele-ophthalmology and Mam- } \\
\text { mography }\end{array}$ & $\begin{array}{l}\text { Tele-ophthalmology enables health professionals to take oc- } \\
\text { ular images / a technique using X-rays to diagnose and locate } \\
\text { tumors of the breasts. }\end{array}$ & $\begin{array}{l}\text { Old Methods of diagnosis by } \\
\text { lenses }\end{array}$ \\
\hline $\begin{array}{l}\text { LASIK (Laser-Assisted in Situ } \\
\text { Keratomileusis) }\end{array}$ & Eye surgery in which tissue is removed using a laser. & Biologically-based therapies \\
\hline Digital Mammography & Examine breast tissue for breast cancer. & Manual Diagnostic \\
\hline Retail Clinics and Medical Homes & $\begin{array}{l}\text { Retail clinic located in retail stores, supermarkets and phar- } \\
\text { macies may treat simple minor illnesses. }\end{array}$ & $\begin{array}{l}\text { Traditional roles in the health } \\
\text { care delivery system }\end{array}$ \\
\hline 3D printing & To help in preparing tissues for transplants & X ray \\
\hline
\end{tabular}

\subsection{Disruptive Innovative Practices in Five} Groups of Hospitals

India has gained a lot of popularity in Medical Tourism from the past few years and witnesses a growth of Medical
Tourists from all around the world in great numbers because Medical Tourists can avail the best of medical services at very lower costs. Prominent Indian Medical Tourism Hospitals has adopted the following Disruptive Innovation Practices:

Table 2. Showing disruptive innovative practices performed by medical tourism hospitals in India

\begin{tabular}{|c|c|c|c|c|}
\hline $\begin{array}{l}\text { Apollo Medical Tourism } \\
\text { Hospitals }\end{array}$ & $\begin{array}{l}\text { Fortis Medical Tour- } \\
\text { ism Hospitals }\end{array}$ & $\begin{array}{l}\text { Medanta Medical } \\
\text { Tourism Hospitals }\end{array}$ & $\begin{array}{l}\text { Max Medical Tourism } \\
\text { Hospitals }\end{array}$ & AIIMS, Delhi \\
\hline 1.Robotics Surgery (da & 1.Robotics Surgery (da & 1.Robotics Surgery (da & 1.Robotics Surgery (da & 1.Robotics Surgery (da \\
\hline Vinci Surgical System) & Vinci Surgical System) & Vinci Surgical System) & Vinci Surgical System) & Vinci Surgical System) \\
\hline $\begin{array}{l}\text { 2.Trans Oral Robotic } \\
\text { Surgery }\end{array}$ & $\begin{array}{l}\text { 2.Trans Oral Robotic } \\
\text { Surgery }\end{array}$ & $\begin{array}{l}\text { 2.Trans Oral Robotic } \\
\text { Surgery }\end{array}$ & $\begin{array}{l}\text { 2.Trans Oral Robotic } \\
\text { Surgery }\end{array}$ & $\begin{array}{l}\text { 2.Trans Oral Robotic } \\
\text { Surgery }\end{array}$ \\
\hline 3. Cyber Knife Robotic & 3. Telemedicine & 3.Telemedicine & 3.Telemedicine & 3.Telemedicine \\
\hline Radio Surgery System & & & & \\
\hline $\begin{array}{l}\text { 4. } 320 \text { Slice CT Scanner } \\
\text { Technology }\end{array}$ & $\begin{array}{l}\text { 4. Electronic Medical- } \\
\text { Records (EMRs) }\end{array}$ & $\begin{array}{l}\text { 4. Electronic Medical- } \\
\text { Records (EMRs) }\end{array}$ & $\begin{array}{l}\text { 4. Electronic Health } \\
\text { Records (EHRs) }\end{array}$ & $\begin{array}{l}\text { 4. Electronic Health } \\
\text { Records (EHRs) }\end{array}$ \\
\hline 5. True Beam STX System & $\begin{array}{l}\text { 5.High intensity } \\
\text { focused ultra- } \\
\text { sound (HIFU) }\end{array}$ & $\begin{array}{l}\text { 5.High intensity } \\
\text { focused ultra- } \\
\text { sound (HIFU) }\end{array}$ & $\begin{array}{l}\text { 5.High intensity focused } \\
\text { ultrasound (HIFU) }\end{array}$ & $\begin{array}{l}\text { 5.High intensity focused } \\
\text { ultrasound (HIFU) }\end{array}$ \\
\hline 6. G (Gravity) Scan & 6. $3 \mathrm{D}$ printing & 6. $3 \mathrm{D}$ printing & 6. $3 \mathrm{D}$ printing & 6. 3D printing \\
\hline 7. Telemedicine & & & & \\
\hline 8. Electronic Medical & & & & \\
\hline Records (EMRs) & & & & \\
\hline 9.mHealth & & & & \\
\hline 10. Tele-cardiology & & & & \\
\hline $\begin{array}{l}\text { 11.High intensity focused } \\
\text { ultrasound (HIFU) }\end{array}$ & & & & \\
\hline 12. Digital Mammography & & & & \\
\hline
\end{tabular}


Observations and interpretations: The above table shows out of five leading Medical Tourism Hospitals in India that the Apollo Group Hospitals has adopted maximum Disruptive Innovation Practices to stimulus medical tourists from all over the world.

\subsection{Treatment Cost Comparison:}

Observation and interpretation: As per the above report generated by FICCI and KPMG, India ranks one of the top three countries in the world for Medical Tourism. On average, the patient can save 65 to $90 \%$ of the treatment cost in India depending on the type of treatment needed. Out of given seven countries, the costs of medical care in Indian Medical Hospitals are lowest to attract the International Tourists.

\section{Conclusion}

- The Disruptive Innovative Practices in Medical care are different in the sense that the disruptive actor is costlier than the disrupted actors (Market, Innovation and Organization). The effective overall cost of management of diseases and disorders is cheaper in long run but disruptive practices increase the immediate cost of management of diseases.

- The medical tourism industry in India is distributed as clusters of tourism hospitals in India. The majority of tourism hospitals are identifiable in three main clusters i.e., North India, South India and South West clusters. These hospitals can be studied in major cities like Mumbai, Delhi and NCR, Chennai, Calcutta and Hyderabad.

- The tourism hospitals are bound to adopt Disruptive Innovative Practices in medical care services in order to compete in Global International Market and make reasonable profits and revenues.

- The accreditations have been associated with the development of medical tourism industry globally. The accreditations also demand the adoption of disruptive innovations and technologies in medical care.

- The authors have noticed that there is a positive relation between growth of medical tourism industry and adoption of disruptive innovative practices. Lastly, it has been concluded that the Disruptive Innovative Practices are important and useful for all the stakeholders that are associated with healthcare as well as hospital services.

Table 3. Showing treatment cost comparison of common procedures

\begin{tabular}{|c|c|c|c|c|c|c|c|}
\hline \multicolumn{8}{|c|}{ Treatment Cost Comparison } \\
\hline Procedures & US (\$) & Costa Rica (\$) & India (\$) & Korea $(\$)$ & Mexico (\$) & Thailand (\$) & Malaysia (\$) \\
\hline Heart Bypass & $\$ 144,000$ & $\$ 25,000$ & $\$ 5,200$ & $\$ 28,900$ & $\$ 27,000$ & $\$ 15,121$ & $\$ 11,430$ \\
\hline Angioplasty & $\$ 57,000$ & $\$ 13,000$ & $\$ 3,300$ & $\$ 15,200$ & $\$ 12,500$ & $\$ 3,788$ & $\$ 5,430$ \\
\hline Heart Valve Replacement & $\$ 170,000$ & $\$ 30,000$ & $\$ 5,500$ & $\$ 43,500$ & $\$ 18,000$ & $\$ 21,212$ & $\$ 10,580$ \\
\hline Hip Replacement & $\$ 50,000$ & $\$ 12,500$ & $\$ 7,000$ & $\$ 14,120$ & $\$ 13,000$ & $\$ 7,879$ & $\$ 7,500$ \\
\hline Hip Resurfacing & $\$ 50,000$ & $\$ 12,500$ & $\$ 7,000$ & $\$ 15,600$ & $\$ 15,000$ & $\$ 15,152$ & $\$ 12,350$ \\
\hline Knee Replacement & $\$ 50,000$ & $\$ 11,500$ & $\$ 6,200$ & $\$ 19,800$ & $\$ 12,000$ & $\$ 12,297$ & $\$ 7,000$ \\
\hline Spinal Fusion & $\$ 100,000$ & $\$ 11,500$ & $\$ 6,500$ & $\$ 15,400$ & $\$ 12,000$ & $\$ 9,091$ & $\$ 6,000$ \\
\hline Dental Implant & $\$ 2,800$ & $\$ 900$ & $\$ 1,000$ & $\$ 4,200$ & $\$ 1,800$ & $\$ 3,636$ & $\$ 345$ \\
\hline Lap Band & $\$ 30,000$ & $\$ 8,500$ & $\$ 3,000$ & N/A & $\$ 6,500$ & $\$ 11,515$ & N/A \\
\hline Breast Implants & $\$ 10,000$ & $\$ 3,800$ & $\$ 3,500$ & $\$ 12,500$ & $\$ 3,500$ & $\$ 2,727$ & N/A \\
\hline Rhinoplasty & $\$ 8,000$ & $\$ 4,500$ & $\$ 4,000$ & $\$ 5,000$ & $\$ 3,500$ & $\$ 3,901$ & $\$ 1,293$ \\
\hline Face Lift & $\$ 15,000$ & $\$ 6,000$ & $\$ 4,000$ & $\$ 15,300$ & $\$ 4,900$ & $\$ 3,697$ & $\$ 3,440$ \\
\hline Hysterectomy & $\$ 15,000$ & $\$ 5,700$ & $\$ 2,500$ & $\$ 11,000$ & $\$ 5,800$ & $\$ 2,727$ & $\$ 5,250$ \\
\hline Gastric Sleeve & $\$ 28,700$ & $\$ 10,500$ & $\$ 5,000$ & N/A & $\$ 9,995$ & $\$ 13,636$ & N/A \\
\hline Gastric Bypass & $\$ 32,972$ & $\$ 12,500$ & $\$ 5,000$ & N/A & $\$ 10,950$ & $\$ 16,667$ & $\$ 9,450$ \\
\hline Liposuction & $\$ 9,000$ & $\$ 3,900$ & $\$ 2,800$ & N/A & $\$ 2,800$ & $\$ 2,303$ & $\$ 2,299$ \\
\hline Tummy Tuck & $\$ 9,750$ & $\$ 5,300$ & $\$ 3,000$ & N/A & $\$ 4,025$ & $\$ 5,000$ & N/A \\
\hline Lasik (both eyes) & $\$ 4,400$ & $\$ 1,800$ & $\$ 500$ & $\$ 6,000$ & $\$ 1,995$ & $\$ 1,818$ & $\$ 477$ \\
\hline Cornea (both eyes) & N/A & $\$ 4,200$ & N/A & $\$ 7,000$ & $\mathrm{~N} / \mathrm{A}$ & $\$ 1,800$ & N/A \\
\hline Retina & N/A & $\$ 4,500$ & $\$ 850$ & $\$ 10,200$ & $\$ 3,500$ & $\$ 4,242$ & $\$ 3,000$ \\
\hline IVF Treatment & N/A & $\$ 2,800$ & $\$ 3,250$ & $\$ 2,180$ & $\$ 3,950$ & $\$ 9,091$ & $\$ 3,819$ \\
\hline
\end{tabular}




\section{References}

1. Govindarajan V, Kopalle PK. The usefulness of measuring disruptiveness of innovations ex-post in making ex-ante predictions. Journal of Product Innovation Management. 2006; 23(1):12-6. https://doi.org/10.1111/j.15405885.2005.00176.x

2. Schmidt GM, Druehl CT. When Is a disruptive innovation disruptive? Journal of Product Innovation Management. 2008; 25(4):347-22. https://doi.org/10.1111/j.15405885.2008.00306.x

3. Bower JL, Christensen CM. Disruptive technologies: catching the wave. Harvard Business Review. 1995 Jan-Feb; 73(1):43-10.

4. Prime India Biz Services-Health Tourism Indian. Available from: www.health-tourism-india.com.

5. Smith MD. Disruptive innovation: Can health care learn from other industries? A conversation with Clayton $\mathrm{M}$. Christensen; 2007.Available from: http://content. healthaffairs.org/content/26/3/w288.full

6. Carrera PM, Bridges JFP. Globalisation and Healthcare: Understanding health and medical tourism. Expert review of pharmacoeconomics and Outcomes Research.2006; 6(4):447-7. PMid:20528514. https://doi. org/10.1586/14737167.6.4.447

7. Connell J. Medical tourism: Sea, sun, sand and ... surgery. Tourism Management.2006; 27(6):1093-7. https://doi. org/10.1016/j.tourman.2005.11.005

8. Forgione DA, Smith PC. Medical tourism and its impact on the US health care system. Journal of Health Care Finance. 2007; 34(1):27-8. PMid:18972983.

9. Grennan T. A wolf in sheep's clothing? A closer look at medical tourism. Medical Ethics. 2003; 1(1):50-4.

10. Gahlinger P. The medical tourism travel guide. USA: Sunrise River Press, North Branch; 2008.

11. Kwoh YS, Hou J, Jonckheere EA, Hayati S. A robot with improved absolute positioning accuracy for CT guided stereotactic brain surgery. IEEE Trans Biomed Eng. 1988 Feb; 35(2):153-8. DOI: 10.1109/10.1354. 2013. https://doi. org/10.1109/10.1354

12. Barbash GI, Glied SA. New technology and health care costs- The case of Robot-Assisted surgery. The New England Journal of Medicine. 2010 Aug; 363:701-3. DOI: 10.1056/ NEJMp1006602. https://doi.org/10.1056/NEJMp1006602

13. Apollo Hospitals Enterprise Limited [IN]. Available from: https://www.apollohospitals. com/lets-talk-health/international/2016/02/01/technology-revolution-the-state-of-indian-healthcare-2016/

14. Bradley WG Jr. MR-guided focused ultrasound: a potentially disruptive technology. Journal of the American College of Radiology. 2009 Jul; 6(7):510-3. PMid:19560068. https://doi.org/10.1016/j.jacr.2009.01.004

15. Coye M J, Haselkorn A, DeMello S. Remote patient management: technology-enabled innovation and evolving business models for chronic disease care. Health Affairs (Millwood). 2009 Jan; 28(1):126-35. PMid:19124862. https://doi.org/10.1377/hlthaff.28.1.126
16. Benner M. Catching up in pharmaceuticals: Government policies and the rise of genomics. Australian Health Review. 2004 Nov 8; 28(2):161-70. PMid:15527396. https:// doi.org/10.1071/AH040161

17. Carlson RJ. The disruptive nature of personalized medicine technologies: Implications for the health care system. Public Health Genomics. 2009; 12(3):180-4. PMid:19204421. https://doi.org/10.1159/000189631

18. Conti R, Veenstra DL, Armstrong K, Lesko LJ, Grosse SD. Personalized medicine and genomics: Challenges and opportunities in assessing effectiveness, cost-effectiveness, and future research priorities. Medical Decision Making. 2010 May; 30(3):328--40. PMid:20086232 PMCid:PMC4598076. https://doi.org/10.1177/0272989X09347014

19. Drews J. Strategic trends in the drug industry. Drug Discovery Today. 2003 May 1; 8(9):411-20. https://doi. org/10.1016/S1359-6446(03)02690-4

20. Greenhalgh T, Procter R, Wherton J, Sugarhood P, Hinder $\mathrm{S}$, Rouncefield $\mathrm{M}$. What is quality in assistive living technology? The ARCHIE framework for effective telehealth and telecare services. BMC Medicine. 2015. DOI: 10.1186/ s12916-015-0279-6. https://doi.org/10.1186/s12916-0150279-6

21. Szold A, Bergamaschi R, Broeders I, Dankelman J, Forgione A, Lango T, et al. European Association of Endoscopic Surgeons (EAES) consensus statement on the use of robotics in general surgery. Surg Endosc. 2015; 29:253-35. PMid:25380708. https://doi.org/10.1007/s00464-014-39169

22. Gawede R, Prasad H, Garg P. Life saving disruptions. TechTalk@KPIT. 2014; 7(10).

23. Sultana S, Haque A, Momen A, Yasmin F. Factors affecting the attractiveness of medical tourism destination: an empirical study on India. Iran J Public Health. 2014; 43(7):867-9. Available from: http://www.tandfonline.com/ doi/full/10.1 080/13683500.2014.937324 PMid:25909055 PMCid:PMC4401052

24. Ormond M, Sulianti D. More than medical tourism: Lessons from Indonesia and Malaysia on South-South intra-regional medical travel. Current Issues Tourism 2014. DOI: 10.1080/13683500.2014.937324. https://doi.org/10.10 80/13683500.2014.937324

25. Mochi P, Shetty N, Vahoniya D. Medical tourism-destination India. Commerce and Management.2013; 2(3): 29-10.

26. Mishra R, Shailesh K. Making Indian healthcare market a global medical tourism destination. IOSR Journal of Business and Management. 2012; 2(4):23-5. https://doi. org/10.9790/487X-0242328

27. Underwood HR, Makadon HJ. Medical tourism: Gamechanging innovation or passing fad? Healthcare Financial Management Articles. 2010 Sep; 64(9):112-4, 116, 118.

28. Kane GC, Fichman RG, Gallaugher J, Glaser J. Community relations 2.0. Harvard Business Rev. 2009 Nov; 87(11):45-5. PMid:19891388

29. Burns LR, David G, Helmchen LA. Strategic response by providers to specialty hospitals, ambulatory surgery centers, and retail clinics. Population Health Management. 
2011 Apr; 14(2):69-8. DOI0: 10.1089/pop.2010.0021. Epub 2010 Nov 23. https://doi.org/10.1089/pop.2010.0021

30. Fox N, Ward K, O'Rourke A. The birth of the e-clinic. Continuity or transformation in the UK governance of pharmaceutical consumption? Social Science and Medicine. 2005 Oct; 61(7):1474-84. PMid:16005782. https://doi. org/10.1016/j.socscimed.2005.03.011

31. Levy F. Computers and the supply of radiology services: anatomy of a disruptive technology. Journal of the American College of Radiology. 2008 Oct; 5(10):1067-72. PMid:18812150. https://doi.org/10.1016/j.jacr.2008.05.022

32. Shih G, Lakhani P, Nagy P. Is android or iPhone the platform for innovation in imaging informatics? J Digit Imaging. 2010 Feb; 23(1):2-7. Available from: http://www.ncbi. nlm.nih.gov/pmc/articles/PMC2809941/pdf/10278_2009_ Article_9242.pdf.

33. Potchen EJ, Clarke B. Transformative technology: A conversation with E. James Potchen and Bill Clarke. Interview by John K. Inglehart. Health Affairs. 2007 Mar-Apr; 26(2):227-35. PMid:17298955. https://doi.org/10.1377/ hlthaff.26.2.w227

34. Hillman BJ. The diffusion of new imaging technologies: a molecular imaging prospective. Journal of the American College of Radiology. 2006 Jan; 3(1):33-7. PMid:17412004. https://doi.org/10.1016/j.jacr.2005.08.010

35. Christensen CM. The innovator's dilemma: When new technologies cause great firms to fail. Boston: Harvard Business School Press; 1997.

36. Walsh ST. Roadmapping a disruptive technology: A case study-the emerging microsystems and top-down nanosystems industry. Technological Forecasting and Social Change. 2004; 71(1-2):161-24. Available from: https://doi. org/10.1016/j.techfore.2003. 10.003

37. Maniyka J, Chui M, Bughin J, Dobbs R, Bisson P, Marrs A. Disruptive technologies: Advances that will transform life, business, and the global economy. McKinsey Global Institute; 2013 May.

38. Halamandaris VJ. Telemedicine revolution makes the home the center of health care. Caring. 2004 Jul; 23(7):52-5. PMid:15341303

39. Windle J, Van-Milligan G, Duffy S, McClay J, Campbell J. Web-based physician order entry: an open source solution with broad physician involvement. AMIA Annual Symposium Proceedings; 2003. p. 724-7. Available from: http://
www.ncbi.nlm.nih.gov/pmc/articles/PMC1480193/pdf/ amia2003_0724.pdf

40. Westbrook JI, Braithwaite J. Will information and communication technology disrupt the health system and deliver on its promise? The Medical Journal of Australia. 2010 Oct 4; 193(7):399-1. PMid:20919970.

41. Topol EJ. Transforming medicine via digital innovation. Science Translational Medicine. 2010 Jan 27; 2(16):16cm4. PMCid:PMC3756088. https://doi.org/10.1126/scitranslmed.3000484

42. Auerswald P. Healthcare in the home: How distributed health service delivery can reduce costs and improve outcomes. GMU school of public policy research paper No. 155; 2015. Available from: http://ssrn.com/abstract $=2550739$

43. Venkatramanan P, Rathina I. Healthcare leveraging internet of things to revolutionize healthcare and wellness. IT Services Business Solutions Consulting. Tata Consultancy Services Limited; 2014. PMCid:PMC4018955

44. Shah SG, Fitton R, Hannan A, Fisher B, Young T, Barnett J. Accessing personal medical records online: A means to what ends? International Journal of Medical Informatics. 2015; 84(2):111-7. PMid:25453275. https://doi. org/10.1016/j.ijmedinf.2014.10.005

45. Christensen CM, Grossman JH, Hwang J. The innovator's prescription: A disruptive solution for health care. New York, USA: McGraw-Hill; 2008.

46. Downing GJ. Policy perspectives on the emerging pathways of personalized medicine. Dialogues in Clinical Neurosciences. 2009; 11(4):377-87. PMid:20135895 PMCid:PMC3181936

47. Christensen CM, Raynor ME. The Innovator's Solution: Creating and sustaining successful growth. Boston: MA: Harvard Business School Press; 2003.

48. Markides C. Disruptive innovation: In need of better theory. Journal of Product Innovation Management. 2006; 23(1):19-6. https://doi.org/10.1111/j.15405885.2005.00177.x

49. Harvard Medical School. Personally controlled Health Record Infrastructure. Boston, Mass: Harvard Medical School; 2006. Available from: www.pchri2006.org

50. Press Information Bureau, Government of India. 2016 May 22. Available from: http://pib.nic.in/newsite/PrintRelease. aspx?relid $=145527$ 